\title{
Aqra Anticline: A Growing Structure in the Iraqi Kurdistan Region
}

\author{
Ala A. Ghafur, Varoujan K. Sissakian, Hawkar A. Abdulhaq and Hassan O. Omer \\ Department of Natural Resources Engineering and Management, University of Kurdistan Hewler, \\ Kurdistan Region - F.R. Iraq
}

\begin{abstract}
Aqra anticline is a doubly plunging anticline, oriented NW-SE with a steep southwestern limb and even overturned. Geomorphological features are interpreted using satellite images; as a result, it was found that the anticline shows clear geomorphological and structural features which indicate the lateral growth of the anticline. Among those features are water gaps, wind gaps, forkedshaped valleys, curved valleys, inclined valleys, and dislocated and abandoned alluvial fans. Some of the vague interpreted features were checked and confirmed in the field.
\end{abstract}

Index Terms-Aqra anticline, En-echelon plunging, Lateral growth, Radial valleys, Water gap.

\section{INTRODUCTION}

In tectonically active areas such as the Iraqi Kurdistan territory, which forms the Northeastern part of the Arabian plate, the lateral growth of anticlines is a very common phenomenon (Blanc, et al., 2003; Bennett, et al., 2005; Ramsey, et al., 2008). The existing anticlines in the region and associated main thrust faults within the anticlines are developed due to the exerted stress forces by the collision of the Arabian plate with the Iranian plate, with a convergent tectonic plate boundary (Alavi, 2004; Allen, et al., 2004). Moreover, mountain building and landscape evolution are controlled by interactions between river dynamics and tectonic forces. Indirect information on tectonic activity can be provided by landscape geomorphology and drainage patterns (Oberlander, 1985; Alvarez, 1999; Burbank and Pinter, 1999; Keller, et al., 1999; Keller and Pinter, 2002; Bretis, et al., 2011; Collignon, et al., 2016). The described geomorphic criteria of many researchers, for example, Keller, et al. (1999) and Keller and Pinter (2002) can be used for the evaluation of fold growth. Among the criteria are: (1) The deformation of progressively younger deposits or landforms, (2) the development of characteristic asymmetric

ARO-The Scientific Journal of Koya University Volume VII, No.2 (2019), Article ID: ARO.10535, 7 pages DOI: 10.14500/aro.10535

Received 31 May 2019; Accepted 07 September 2019

Regular research paper: Published 10 December 2019

Corresponding author's e-mail: ala.abdulla@ukh.edu.krd

Copyright (C) 2019 Ala A. Ghafur, Varoujan K. Sissakian, Hawkar A. Abdulhaq, Hassan O. Omer. This is an open-access article distributed under the Creative Commons Attribution License. drainage patterns, (3) the occurrence of a series of wind gaps with decreasing elevation in the propagation direction, (4) the development of water gaps (WG), (5) the presence of en-echelon plunges, and (6) the development of crossshaped valleys, axial valleys, fork-shaped valleys, and curved valleys. However, the presence of one or two of the mentioned criteria does not mean they indicate lateral growth of a fold. Many of those criteria collectively and repeatedly should be present to indicate the lateral growth.

The studied area includes Aqra anticlines, which is located Northwest of Erbil city, near to Aqra town within the Iraqi Kurdistan Region (Fig. 1). It forms an outstanding continuous mountain range with Peris anticline (Mountain) toward the East and Shaikhan anticline toward the west.

The aim of the current study is to confirm the lateral growth of the Aqra anticline using geomorphological features which are developed in the anticline. The recognition of the features was done by the interpretation of high-quality satellite images and field investigation.

\section{A. Previous Studies}

Tectonic geomorphological studies are not common in the Kurdistan Region as a whole and particularly in the studied area and near surroundings; among them are:

Sissakian (2010) conducted a tectonic geomorphological study of the Derbendi Bazian gorge, which represents a wind gap and attributed to the development of the gorge to neotectonic activity. Sissakian and Abdul-Jabbar (2010) conducted a study about the transversal gorges, among them are Basara gorge, which represents a WG and concluded that the gorge developed due to neotectonic activity. Sissakian and Fouad (2014) and Sissakian, et al. (2019) updated the geological map of Erbil and the Mahabad Quadrangles at a scale of 1:250,000. Aqra anticline is located within.

The updated map and demonstrated the details of the structural features, but the lateral growth of the anticline was not mentioned. Sissakian, et al. (2014) conducted a geomorphological study of the high folded zone and attributed the developed gorges in Aqra anticline to the lateral propagation (growth) of the anticlines. Al-Kubaisi and Abdul Jab'bar (2015) conducted a morphotectonic study of three folds in the Kurdistan region and their effect on the drainage systems. They indicated high tectonic activity and low maturity of the drainage basins in the studied anticlines. Sissakian, et al. (2018) 


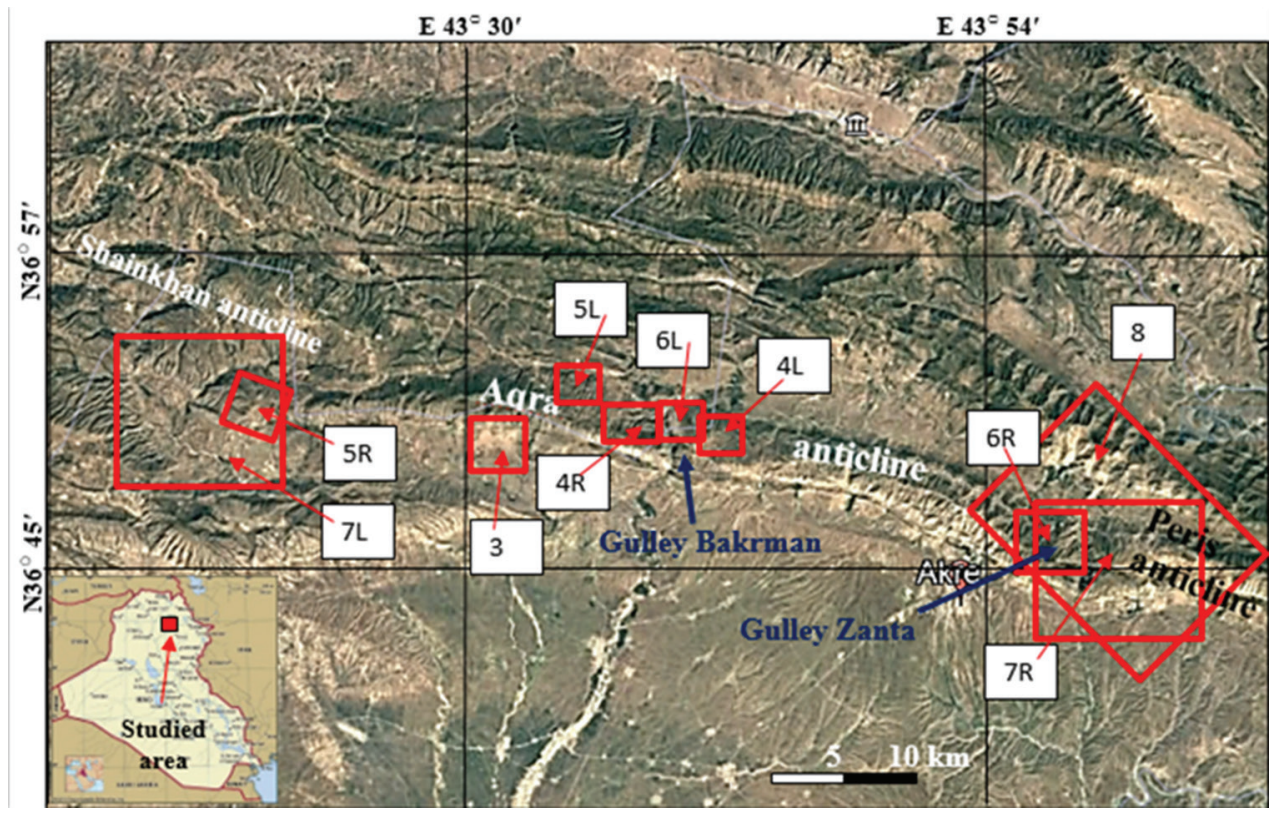

Fig. 1. Satellite image of the study area showing the Aqra anticline. Location of Figures 3-8 is identified in red boxes.

conducted a tectonic geomorphological study on the Qara Dagh anticline to indicate its lateral growth by means of the same geomorphological forms which are used in the current study.

Worldwide studies dealing with the concept of current study are very common; among them are: Cartwright, et al. (1995) conducted a geomorphological study to deduce the fault growth by segment linkage from the Canyonlands Grabens of SE Utah, USA. Bennett, et al. (2005) conducted a geomorphological study in South Rough Ridge, Central Otago, and New Zealand to deduce the lateral growth of a ridge along a blind fault. Mumipour and Najad (2011) and Mosavi and Arian (2015) conducted tectonic geomorphological studies in the Zagros Belt; Iran using geomorphological features to deduce the growth of anticlines.

\section{Materials AND Methods}

To perform the current work and fulfill its aim, the following materials were used:

- Geological maps at a scale of 1:250,000

- Topographical maps at a scale of 1:100,000

- Satellite images of high quality to recognize geomorphological features

- Flied work was conducted to check the recognized geomorphological features.

To recognize geomorphological features which indicate the lateral growth of an anticline, the opinions of different researchers have been considered in the current study to indicate the lateral growth of the Aqra anticline, and to confirm the achieved conclusions from the current work. Among those researchers are Keller, et al. (1999), Keller and Pinter (2002), Ramsey, et al. (2008), and Collignon, et al. (2016).

Different geomorphological features were recognized by utilizing available topographical and geological maps of different scales, digital elevation model images, FLASH
Earth, and software such as Global Mapper. The obtained features were used to signify the lateral growth of the Aqra anticline. Those indicated features were used to indicate the lateral growth of the Aqra anticline. Different geomorphological studies in the Zagros Range were reviewed to deduce the indication for the growth of anticlines, their evolution, and their current shapes. Different valley shapes which exist in the Aqra anticline and confirm its lateral growth, were recognized using many research prefects from: Keller, et al. (1999), Keller and Pinter (2002), Ramsey, et al. (2008), and Collignon, et al. (2016). The recognized geomorphological features in the networks of mountain belts are perhaps the most sensitive indicators of horizontal and vertical surface deformation, at least on Holocene time scale (Burbank and Anderson, 2001).

\section{Geological Setting}

The geological setting of the studied area is briefed hereinafter; including geomorphology, tectonics, and structural geology as well as stratigraphy.

Geomorphologically, the studied area is mountainous with very rugged cliffs and steep slopes. The main geomorphological forms are: Anticlinal ridges, abandoned alluvial fans, water and wind gaps, extensive karstification, and dissected slopes. The studied area is located in the high folded zone where the Aqra anticline forms the beginning of the high folded zone in the studied area; whereas its southern plain represents the low folded zone. The high folded zone belongs to the Outer Platform of the Arabian plate (Fouad, 2012) and is a part of the Zagros FoldThrust Belt (Alavi, 2004, Ramsey, et al., 2008). The Aqra anticline is a doubly plunging anticline trending NW-SE, with a very steep southwestern limb which exhibits vertical dipping and even overturned beds for long distances. The length and width of the anticline are $55 \mathrm{~km}$ and $6 \mathrm{~km}$, 
respectively. The Southeastern plunge forms an en-echelon plunge with the Peris anticline, whereas the Northwestern plunge is complicated and truncated by many faults which are developed in the carbonates of the Pila Spi Formation, causing wide coverage area for the exposures; accordingly, hindering the normal plunge shape of the anticline (Fig. 2). The exposed formations in the studied area are briefly described hereinafter, from the older to younger. Only those formations which are exposed in Aqra anticlines (Fig. 2) are briefed (Sissakian and Al-Jiburi, 2014 and Sissakian and Fouad, 2014).

\section{Qamchuqa formation (lower cretaceous)}

The formation is exposed only in the core of the Aqra anticline at Al-Khazir river gorge and Gulley Zanta. The formation consists of massive limestone, dolomitic limestone, and dolomite, usually dark gray and light brown in color. The exposed thickness of the formation is about $200 \mathrm{~m}$.

\section{Bekhme formation (upper cretaceous)}

The formation is exposed widely in the Aqra anticline and forms the carapace of Aqra mountain. The formation consists of well-bedded limestone and dolostone, locally bituminous, coralline and recrystallized, very hard, and light gray in color. The thickness is $700 \mathrm{~m}$; however, it decreases in then direction.

\section{Shiranish formation (upper cretaceous)}

The formation is exposed to both limbs of the anticline. The formation consists of thinly well-bedded marly and chalky limestone, white, and grayish white in color, followed (upward) by thinly bedded or papery marl, blue, and gray in color with presence of marly limestone beds too. The thickness of the formation is around $180 \mathrm{~m}$.

\section{Kolosh formation (Paleocene)}

The formation is exposed on both limbs of the anticline as a thin belt. It consists of black shale, claystone, sandstone, and siltstone; some very thin layers of limestone may occur too. The thickness of the formation is $20 \mathrm{~m}$.

\section{Gercus formation (Paleocene-lower Eocene)}

The formation is exposed on both limbs of the anticline as a thin belt, consists of red, claystone, sandstone, and siltstone; some very thin layers of limestone, conglomerate, and very rare gypsum beds may occur too. The thickness of the formation is $40 \mathrm{~m}$.

\section{Pila Spi formation (Eocene)}

The formation is exposed on both limbs of the anticline as a thin belt and is very widely exposed in the Northwestern plunge area. It consists of well-bedded carbonate rocks. The thickness of the formation is about $85 \mathrm{~m}$.

\section{RESULTS AND INTERPRETATIONS}

Geomorphological features which can be used as markers such as wind gaps and WGs (or transverse streams) have been extensively used to define the style of deformation and to quantify both the rate and the direction of propagation (or the lateral growth) of fault and fold segments (Burbank and Pinter, 1999; Keller, et al., 1999; Delcailleau, et al., 2006; Vergés, 2007; Ramsey, et al., 2008; Bretis, et al., 2011). WGs represent valleys that are developed by carving the exposed rocks during fold growth and that still host a flowing stream, whereas wind gaps constitute of similar valleys that are presently dry; witnessing previous WG, and the rate of the river incision is less than the rate of the fold growth.

The rate of rock and surface uplift, which shapes landscapes are controlled by deformation, climate, and rock properties. Understanding the interaction between these parameters and how they determine the formation of wind gaps, is a question with direct implications for predicting the release of sediments in local basins and at the outlet of fluvial basins (Collignon, et al., 2016). To understand the development of WGs and their changes (locally) to wind gaps, and the radial valleys, the opinion of Ramsey, et al. (2008) is adopted in the current study.

Abandoned alluvial fans are also good indicators for active tectonics in the area, where such fans occur. Among the active tectonics is the lateral growth and the uplift of folds (Skilodimou, et al., 2014); however, the climate change for the existence of abandoned alluvial fans cannot be ignored. Fig. 3 shows a large alluvial fan with two phases; an abandoned fan followed by an active fan.

Axial valleys and cross-shaped valleys on top of elevated areas are good indications for active tectonics (Cannat, et al., 1999). Fig. 4 shows the axial valley and cross-shaped valley at the Aqra anticline, indicating the lateral growth of the anticline.

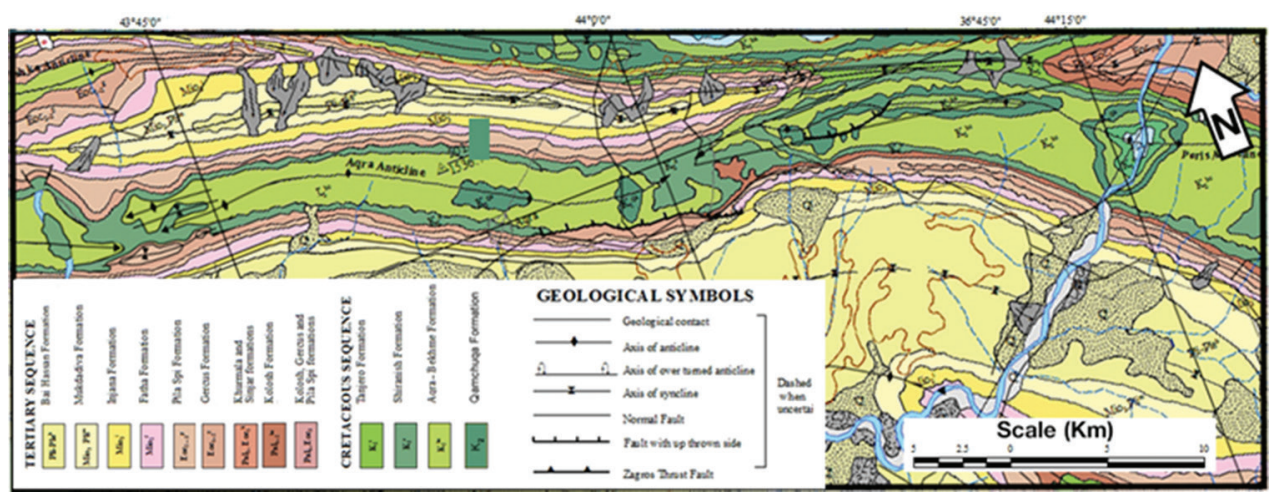

Fig. 2. Geological map of the studied area (after Sissakian, et al., 2019). 
Fork-shaped valleys and radial valleys are also good indicators for the lateral growth of folds (Keller and Pinter, 2002; Ramsey, et al., 2008). Both types of valleys are very common along both limbs of the Aqra anticline (Fig. 5) indicating the lateral growth of the anticline.
Water and wind gaps are also excellent indications for the lateral growth of any fold in which these phenomena are developed (Ramsey, et al., 2008; Collignon, et al., 2016). At the Aqra anticline two WGs (Gulley Bakrman and Gulley Zanta) and one wind gap are developed (Fig. 6).

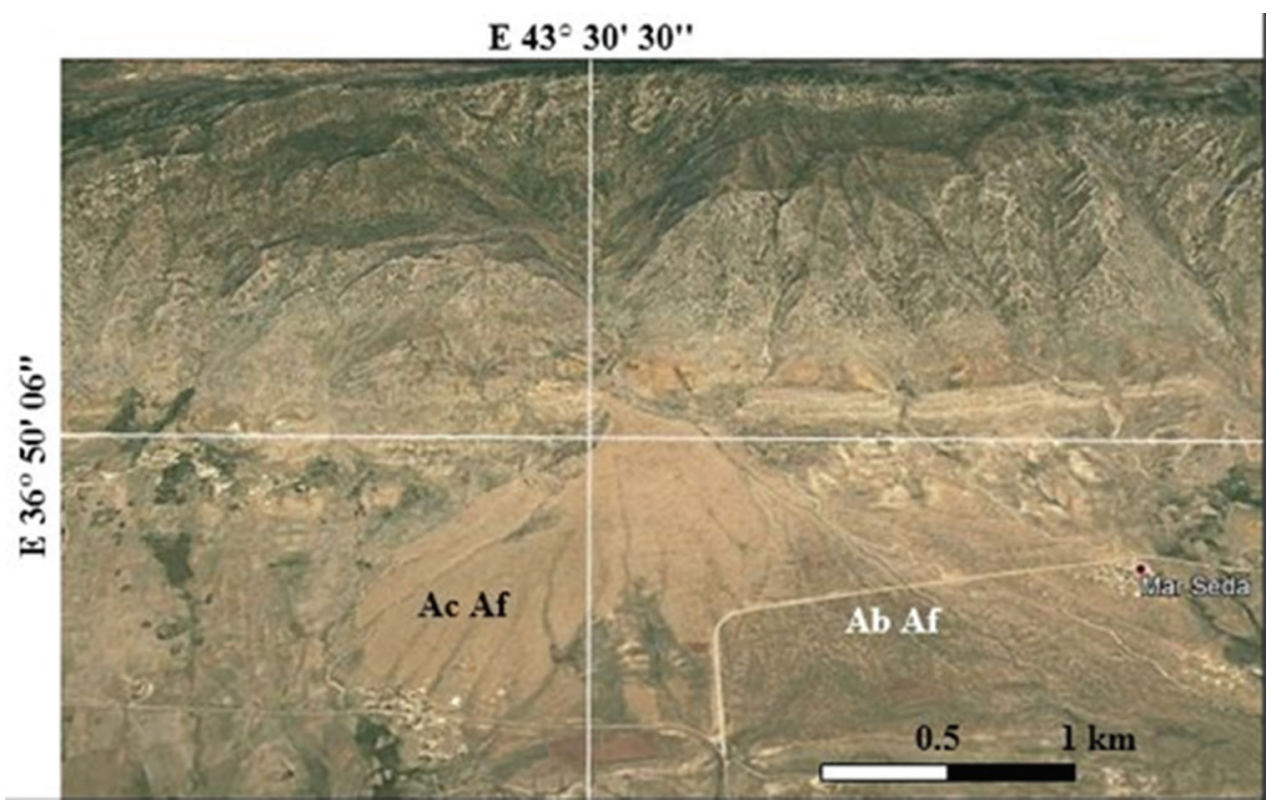

Fig. 3. Satellite image of an alluvial fan West of Aqra town. Abandoned alluvial fan (Ab Af) and an active alluvial fan (Ac Af).
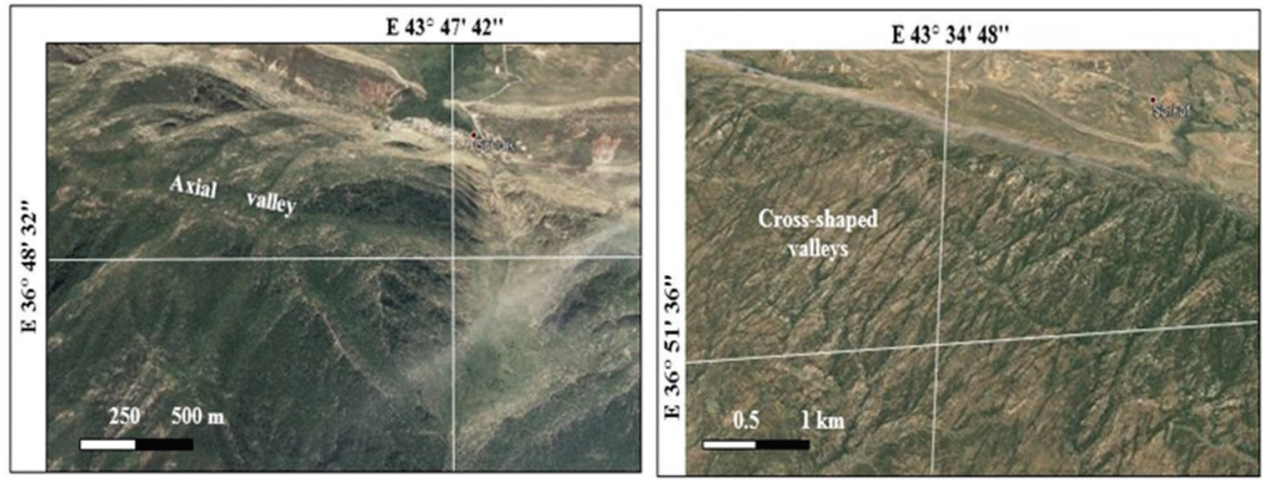

Fig. 4: (Left) Satellite image facing South. (Left) axial valley, (Right) cross-shaped valleys.
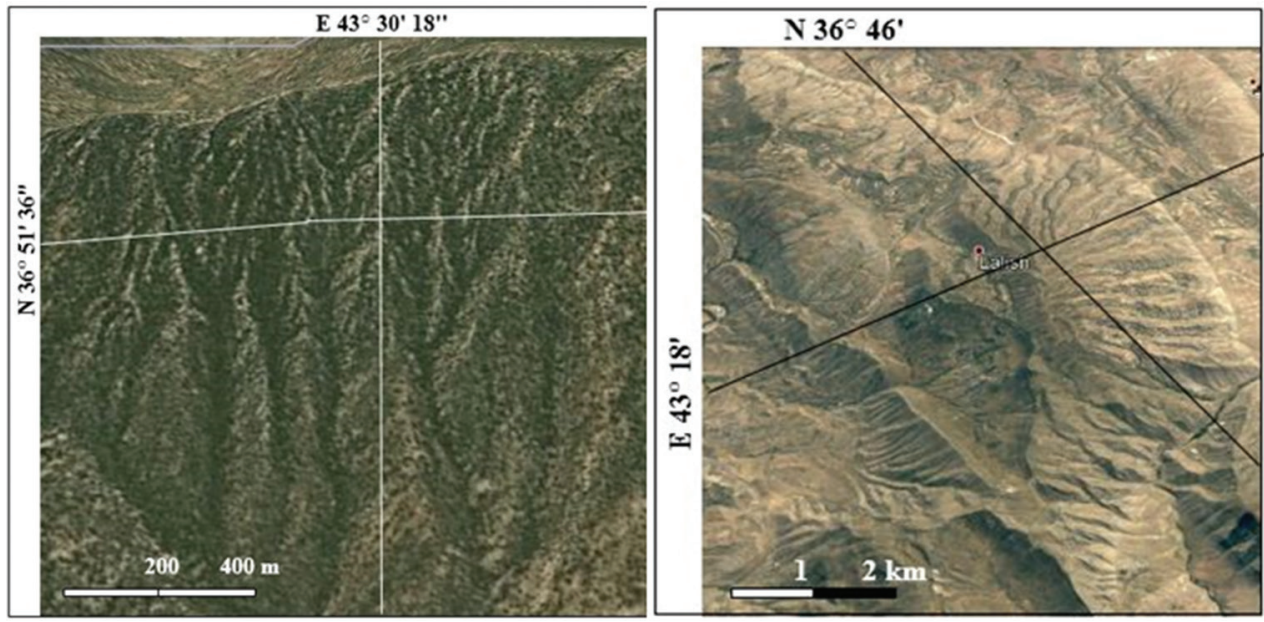

Fig. 5. (Left) Satellite image facing South showing fork-shaped valleys, (Right) Satellite image facing Southwest showing radial valleys. 
En-echelon plunges of folds are also an indication for the lateral fold growth (Collignon, et al., 2016). The Aqra anticline is a doubly plunging anticline trending NW-SE. The Southeastern plunge with the Peris anticline is of enechelon type (Fig. 7 Right). Whereas, the Northwestern plunge is highly complicated and faulted (Sissakian, et al., 2019); therefore, it is not so clear (Fig. 7 Left).

\section{DISCUSSION}

Aqra anticline exhibits lateral growth mainly toward the Southeast as indicated by en-echelon plunging (Fig. 7, Right) as well as the presence of other indications; like abandoned alluvial fan (Fig. 3), axial valleys (Fig. 4, Left), cross-shaped valleys (Fig. 4, Right), fork-shaped valleys (Fig. 5, Left), radial valleys (Fig. 5, Right), and WGs (Fig. 6). The rate of stream incision is more than the growth rate of the Aqra anticline, as indicated by the presence of two WGs (Fig. 6). Moreover, the growth rate of the Peris anticline is more than that of the Aqra anticline as indicated from the en-echelon plunges, for both anticlines (Fig. 7, Right and Fig. 8). The Northwestern plunge of the Peris anticline is pushing more than that of Aqra anticline. This is indicated by the closure of the Northern part of a WG, which was present in the extreme Southeastern part of the Aqra anticline. The relic of the WG is present as a valley which is dissected into many parts. Formerly, it was flowing from A-B-C-D (Fig. 8). A landslide (near point A, Fig. 8) has blocked the entrance of the WG.

The continuous growth of the Peris anticline with a rate of more than that of the Aqra anticline is causing the blockage of the WG represented by Gulley Zanta (Fig. 6, Right and Fig. 8). Moreover, the small and low ridge (point E at Fig. 8) will disappear causing the merging of both valleys $\mathrm{C}-\mathrm{D}$ and F-G. After the blockage of Gulley Zanta (WG, Fig. 8), the accumulated water in Nahleh Stream will start carving the previously existing WG, near the Northwestern plunge of the Peris anticline starting from point A (Fig. 8) and continue carving, to release the previously existing WG. However, this is controlled by the rate of the lateral growth of both anticlines and the incision rate of the streams, which depends mainly on the amount of rainfall and snowfall.

The Northwestern plunge of the Aqra anticline shows strange behavior exhibiting a wide coverage area, which is mainly covered by the carbonates of the Pila Spi Formation (Fig. 2). The exposures show dipping beds in different directions, hindering the normal shape of a plunging anticline. This is attributed most probably to the rate of upward growth and is more than the rate of the lateral growth. It is worth mentioning that the plunge area is highly deformed, faulted, and faces many adjacent anticlines (Northwest wards, North wards, and Southwest wards).

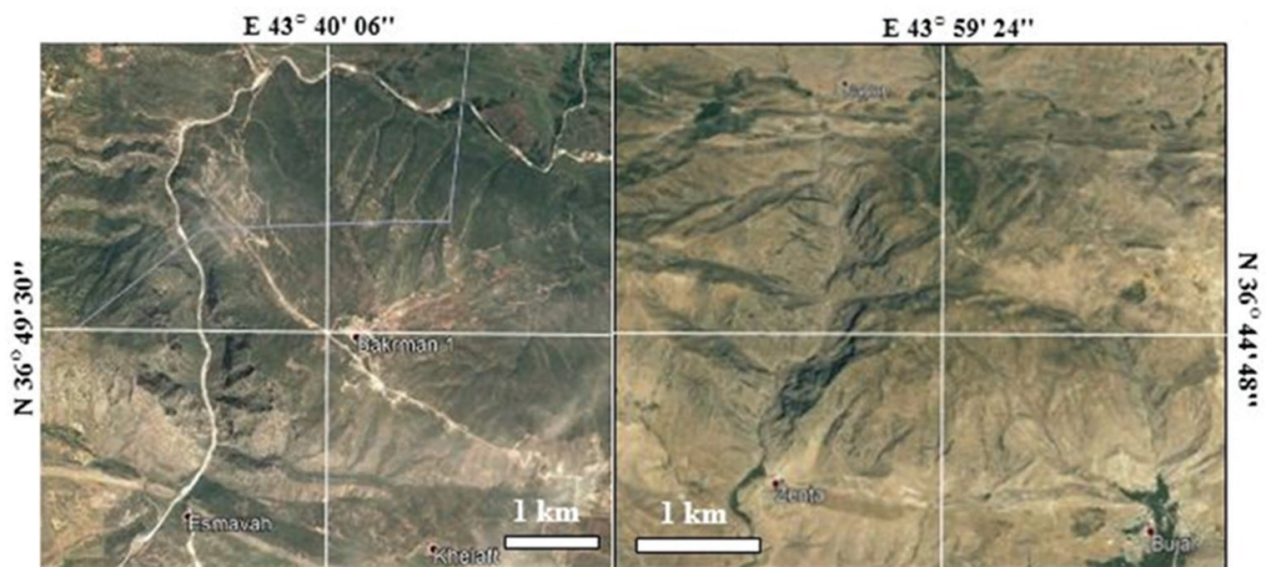

Fig. 6. Satellite image of two water gaps, (Left) Gully Bakrman, (Right) Gulley Zanta.

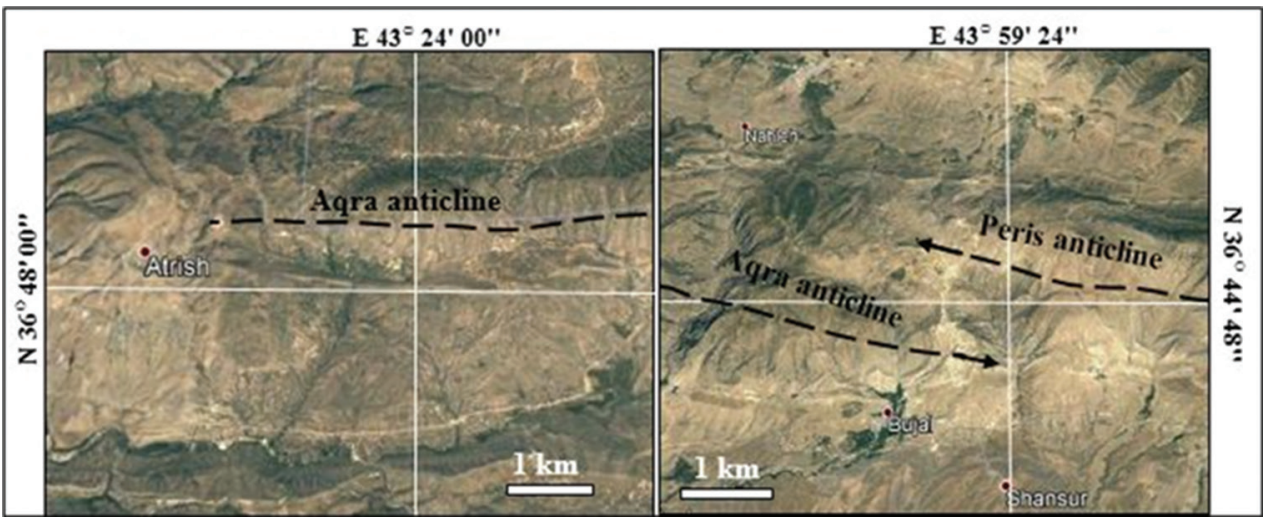

Fig. 7. Satellite image of Aqra anticline. (Left) The Northwestern plunge, note the complicated plunge due to faulting, (Right) En-echelon plunge of Aqra and Peris anticlines. 


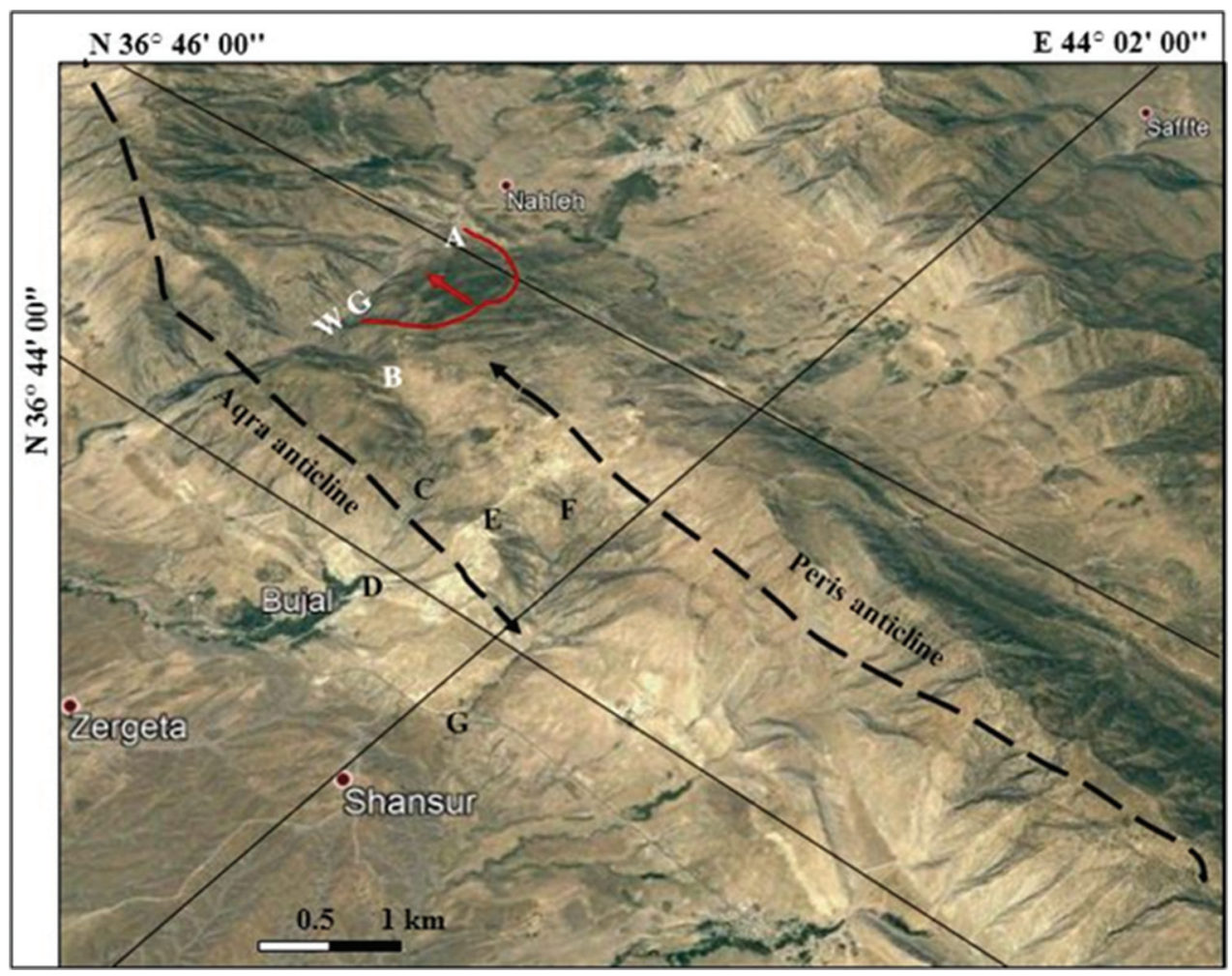

Fig. 8. Satellite image facing northeast, showing plunges of the Aqra and Peris anticlines.

\section{CONCLUSION}

The Aqra anticline is exhibiting lateral growth toward the southeast, as indicated by many geomorphological features such as WGs, abandoned alluvial fan, cross-shaped valleys, radial valleys, axial valleys, and fork-shaped valleys. The rate of the incisions of the streams is more than the rate of the lateral growth of the anticline. However, the rate of the lateral growth of the Peris anticline is more than that of the Aqra anticline, which is pushing toward Northwest, and its continuous growth will cause the blockage of Galley Zanta. The Northwest plunge area exhibits abnormal forms of very wide outcrops of the Pila Spi Formation. The plunge area of Aqra anticline is highly deformed and hinders the normal plunge form.

\section{ACKNOWLEDGMENT}

The authors express their thanks to the authorities of the University of Kurdistan-Hewler for presenting the required logistics for performing the current research.

\section{REFERENCES}

Alavi, M., 2004. Regional stratigraphy of the zagros fold thrust belt of iran and its proforeland evolution. American Journal of Science, 304, pp.1-20.

Al-Kubaisi, M.S., and Abdul, J.M.F., 2015. Effect of lateral propagation of selected folds on streams, Sulaimaniyia Area, NE Iraq. Iraqi Bulletin of Geology and Mining, 11(1), p.95-124.

Allen, M., Jackson, J., and Walker, R., 2004. Late Cenozoic reorganisation of the Arabia Eurasia collision and the comparison of short-term and long-term deformation rates. Tectonics, 23, p.TC2008.
Alvarez, W., 1999, Drainage on evolving fold-thrust belts: A study of transverse canyons in the Apennines. Basin Research, 11, pp.267-284.

Bennett, E., Youngson, J., Jackson, J., Norris, R., Raisbeck, G., Yiou, F., and Fielding, E., 2005. Growth of South Rough Ridge, Central Otago, New Zealand: Using in situ cosmogenic isotopes and geomorphology to study an active, blind reverse fault. Journal of Geophysics Researches, 110, p.B02404.

Blanc, E.J.P., Allen, M.B., Inger, S., and Hassani, H., 2003. Structural styles in the Zagros simple folded zone, Iran. Journal of Geological Society, 160, pp.401-412.

Bretis, B., Bartl, N., and Graseman, B., 2011. Lateral fold growth and linkage in the Zagros fold and thrust belt (Kurdistan, NE Iraq). Basin Research, 23, pp. 615-630.

Burbank, D.W., and Anderson, R.S., 2001. Tectonic Geomorphology. Blackwell Science Malden, MA, USA.

Burbank, D.W., and Pinter, N., 1999. Landscape evolution: The interactions of tectonics and surface processes. Basin Research, 11, pp. 1-6.

Cannat, M., Rommevaux-Jestin, C., Sauter, D., Deplus, C., and Mendel, V., 1999. Formation of the axial relief at the very slow spreading Southwest Indian Ridge $\left(49^{\circ}\right.$ to $\left.69^{\circ} \mathrm{E}\right)$. Journal of Geophysical Research: Solid Earth, American Geophysical Union, 104(B10), pp.22825-22843.

Cartwright, J.A., Trudgill, B., and Mansfield, C.S., 1995. Fault growth by segment linkage: An explanation or scatter in maximum displacement and trace length data from the Canyon lands Grabens of SE Utah. Journal of Structural Geology, 17, pp.1319-1326.

Collignon, M., Yamato, P., Castelltort, S., and Boris, K.B., 2016. Modelling of wind gap formation and development of sedimentary basins during fold growth: Application to the Zagros Fold Belt, Iran. Earth Surface Processes and Landforms, 41(11), p.1521-1535.

Delcailleau, B., Carozza, J.M., and Laville. E., 2006. Recent fold growth and drainage development: The Janauri and Chandigarh anticlines in the Siwalik foothills, Northwest India. Geomorphology, 76, pp. 241-256.

Fouad, S.F., 2012. Tectonic Map of Iraq, Scale 1: 1000 000. $3^{\text {rd }}$ ed. Iraq Geological Survey Publications, Baghdad, Iraq. 
Keller, E.A., and Pinter, N., 2002. Active Tectonics, Earthquakes, Uplift and Landscape. $2^{\text {nd }}$ ed. Prentice Hall, Upper Saddle River, pp.362.

Keller, E.A., Gurrola, L., and Tierney, T.E., 1999. Geomorphic criteria to determine direction of lateral propagation of reverse faulting and folding. Geology, 27(6), p.515-518.

Mosavi, E.J., and Arian, M., 2015. Tectonic geomorphology of Atrak River, NE Iran. Open Journal of Geology, 5, p.106-114.

Mumipour, M., and Najad H.T., 2011. Tectonic geomorphology setting of khayiz anticline derived from GIS processing, Zagros mountain, Iran. Asian Journal of Earth Sciences, 4(3), p.1711-1782.

Oberlander, T.M., 1985. Origin of drainage transverse to structures in orogens. In: Morisawa, M., Hack, J.T., editors. Tectonic Geomorphology, the Binghampton Symposia in Geomorphology. Vol. 15. Allen and Unwin, Boston. pp.155-182.

Ramsey, L.A, Walker, R,T., and Jackson, J., 2008. Fold evolution and drainage development in the Zagros Mountains of Fars Province, SE Iran. Basin Research, 20, pp. $23-48$

Sissakian, V.K., 2010. Neotectonic movements in Darbandi Bazian Area, southwest of Sulaimaniyah city, NE Iraq. Iraqi Bulletin of Geology and Mining, 6(2), pp.57-69.

Sissakian, V.K., Ameen, R.M., and Mohammed, J.G., 2018. Lateral growth of qara dagh anticline, South of Sulaimaniyah city, NE Iraq: A structural geomorphological study. Iraqi Bulletin of Geology and Mining, 14(2), pp.9531-9547.
Sissakian, V.K., and Abdul-Jabbar, M.F., 2010. Morphometry and genesis of the main transversal gorges in North and Northeast Iraq. Iraqi Bulletin of Geology and Mining, 6(1), pp.95-120.

Sissakian, V.K., and Al-Jiburi, B.M., 2014. Stratigraphy. In: Geology of the High Folded Zone. Iraqi Bulletin of Geology and Mining, Iraqi. pp.73-161.

Sissakian, V.K., and Fouad, S.F., 2014. Geological Map of Erbil Quadrangle, Scale 1: $250000.3^{\text {rd }}$ ed. Iraq Geological Survey Publications, Baghdad, Iraq.

Sissakian, V.K., Fouad, S.F., Abdulhaq, H.A., and Omer, H.O., 2019. Geological Map of Erbil and Mahabad Quadrangles, Scale 1: 250000. $3^{\text {rd }}$ ed. Iraq Geological Survey Publications, Baghdad, Iraq.

Sissakian, V.K., Kadhum, T.H., and Abdul Jab'bar, M.F., 2014. Geomorphology. In: The Geology of the High Folded Zone. Iraqi Bulletin of Geology and Mining, Iraqi. pp.7-56.

Skilodimou, H.D., Bathrellos, G.D., Maroukian, H., and Gaki-Papanastassiou, H.K., 2014. Late quaternary evolution of the lower reaches of ziliana stream in South Mt. Olympus (Greece). Geografia Fisica e Dinamica Quaternaria, $37(1)$, pp.43-50.

Vergés, J., 2007. Drainage responses to oblique and lateral thrust ramps: A review. In: Nichols, G., Paola, C., and Williams, E.A., editors. Sedimentary Processes, Environments and Basins: A Tribute to Peter Friend. International Association of Sedimentologists, Blackwell Publishing, Hoboken, New Jersey. pp. $29-47$ 